\title{
Crossed brainstem syndrome revealing bleeding brainstem cavernous malformation: an illustrative case
}

\author{
Nathan Beucler ${ }^{1,2^{*}}$ D, Sébastien Boissonneau ${ }^{1,3}$, Aurélia Ruf ${ }^{4}$, Stéphane Fuentes ${ }^{1}$, Romain Carron $^{3,5}$ and \\ Henry Dufour ${ }^{1,6}$
}

\begin{abstract}
Background: Since the nineteenth century, a great variety of crossed brainstem syndromes (CBS) have been described in the medical literature. A CBS typically combines ipsilateral cranial nerves deficits to contralateral long tracts involvement such as hemiparesis or hemianesthesia. Classical CBS seem in fact not to be so clear-cut entities with up to $20 \%$ of patients showing different or unnamed combinations of crossed symptoms. In terms of etiologies, acute brainstem infarction predominates but CBS secondary to hemorrhage, neoplasm, abscess, and demyelination have been described. The aim of this study was to assess the proportion of CBS caused by a bleeding episode arising from a brainstem cavernous malformation (BCM) reported in the literature.

Case presentation: We present the case of a typical Foville syndrome in a 65-year-old man that was caused by a pontine BCM with extralesional bleeding. Following the first bleeding episode, a conservative management was decided but the patient had eventually to be operated on soon after the second bleeding event.

Discussion: A literature review was conducted focusing on the five most common CBS (Benedikt, Weber, Foville, Millard-Gubler, Wallenberg) on Medline database from inception to 2020. According to the literature, hemorrhagic BCM account for approximately $7 \%$ of CBS. Microsurgical excision may be indicated after the second bleeding episode but needs to be carefully weighted up against the risks of the surgical procedure and openly discussed with the patient.
\end{abstract}

Conclusions: In the setting of a CBS, neuroimaging work-up may not infrequently reveal a BCM requiring complex multidisciplinary team management including neurosurgical advice.

Keywords: Foville syndrome, Crossed brainstem syndrome, Intracranial hemorrhage, Brainstem cavernous malformation, Developmental venous anomaly

\footnotetext{
* Correspondence: nathan.beucler@neurochirurgie.fr

${ }^{1}$ Department of Neurosurgery, Timone University Hospital, APHM, 264 rue Saint-Pierre, 13005 Marseille, France

${ }^{2}$ Ecole du Val-de-Grâce, French Military Health Service Academy, 1 place Alphonse Laveran, 75230 Paris Cedex 5, France

Full list of author information is available at the end of the article
}

(c) The Author(s). 2021 Open Access This article is licensed under a Creative Commons Attribution 4.0 International License, which permits use, sharing, adaptation, distribution and reproduction in any medium or format, as long as you give appropriate credit to the original author(s) and the source, provide a link to the Creative Commons licence, and indicate if changes were made. The images or other third party material in this article are included in the article's Creative Commons licence, unless indicated otherwise in a credit line to the material. If material is not included in the article's Creative Commons licence and your intended use is not permitted by statutory regulation or exceeds the permitted use, you will need to obtain permission directly from the copyright holder. To view a copy of this licence, visit http://creativecommons.org/licenses/by/4.0/ The Creative Commons Public Domain Dedication waiver (http://creativecommons.org/publicdomain/zero/1.0/) applies to the data made available in this article, unless otherwise stated in a credit line to the data. 


\section{Background}

The anatomy of the brainstem is notable for comprising the nuclei and fibers of cranial nerves III to XII, long motor and sensory tracts, and crucial vegetative structures for cardio-respiratory functions and wakefulness. As a consequence, the clinical manifestations of brainstem injury vary from focal symptoms such as cranial nerves deficits to signs of long tracts involvement with motor or sensory impairment, and even vegetative state or death. The most frequent etiology of brainstem damage appears to be ischemic stroke [1]. Less frequent causes include multiple sclerosis, brainstem gliomas, brainstem abscesses, and vascular malformations just to cite a few. Among vascular malformations, a brainstem cavernous malformation (BCM) consists of a mulberrylike assembly of thin-walled vascular sinusoids which growth is self-sustained by repeated intralesional microbleed episodes. Yet, BCM may also be responsible for symptomatic extralesional bleedings which can be life threatening. The aim of this report is to present an original case of a genuine crossed brainstem syndrome (CBS) that turned out to be the mode of revelation of a bleeding BCM, and to discuss its frequency and its management.

\section{Case presentation}

A 65-year-old man presented with a 10-day history of sudden onset binocular diplopia and gait disturbance; he also complained of tinnitus. His medical history consisted in chronic glaucoma treated with latanoprost eye droplets. The patient was on daily acetylsalicylic acid for primary prevention of cardiovascular disease. His family medical history revealed an ischemic stroke in one of his sisters and an unexpected death during her sleep in another sister. He also reported a fifty pack-year smoking and admitted chronic alcohol intake. His general practitioner introduced candersartan $4 \mathrm{mg}$ daily upon symptoms onset. Careful neurological examination revealed a left abducens nerve (CN VI) palsy, a left peripheral facial nerve ( $\mathrm{CN}$ VII) palsy, and a contralateral face-sparing hemiparesia (Fig. 1, Video 1). Right-sided mild dysesthesiae were also reported. There was no other cranial nerve deficit, no other focal neurological deficit (FND). There was no headache, no fever, no meningismus. Lab tests did not reveal inflammatory reaction. Magnetic resonance imaging of the brain revealed a BCM located on the left side of the floor of the fourth ventricle with evidence of recent extralesional bleeding. There was no other cerebral cavernous malformation on gradient-echo sequences. The BCM was associated with a developmental venous anomaly (DVA) draining both sides of the cerebellum directly into the vein of Galen (Fig. 2). The co-existence of an ipsilateral deficit of CN VI and VII and a contralateral face-sparing hemiparesia was highly suggestive of the inferior medial pontine syndrome, also known as Foville syndrome. The patient was admitted to

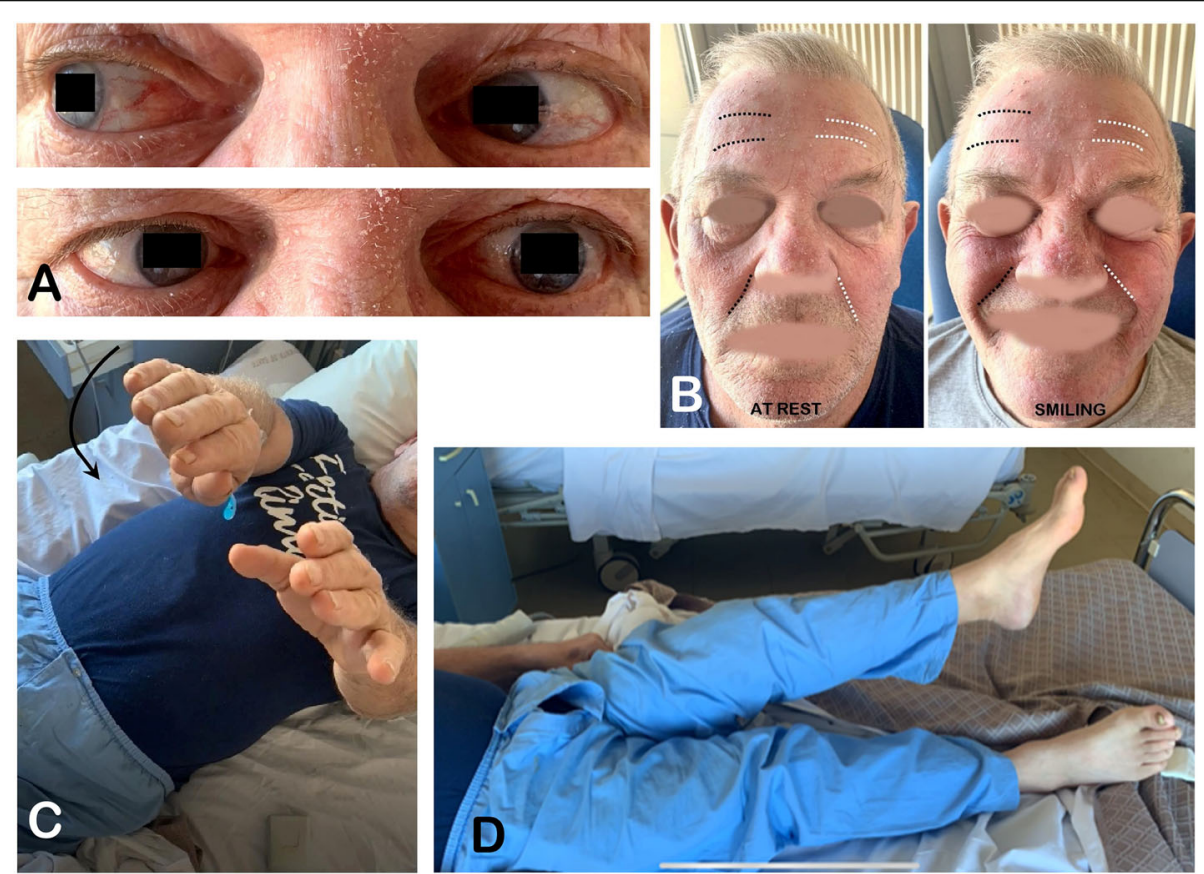

Fig. 1 Clinical examination reveals (a) an abducens nerve palsy and (b) a peripheral facial nerve palsy on the left side, associated with (c,d) a contralateral face-sparing hemiparesis. This crossed brainstem syndrome involves the inferior medial pons and was originally described by Achille Louis Foville in 1859 

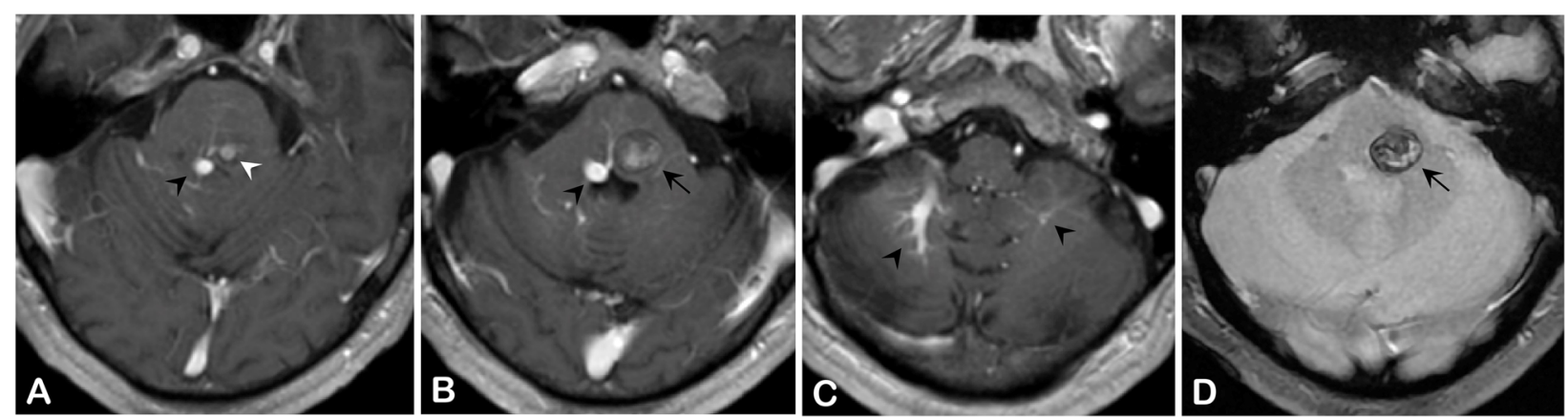

Fig. 2 The cerebral MRI shows (a, white arrowhead, post-contrast T1-weighted sequence) a brainstem cavernous malformation (BCM) associated with (a,b,c, black arrowheads, post-contrast T1-weighted sequence) a bilateral cerebellar developmental venous anomaly (DVA) prevailing on the right side and draining into the vein of Galen. (b, black arrow, post-contrast T1-weighted sequence and D, back arrow, gradient-echo sequence) The BCM was responsible for a medial pontine hematoma

the neurosurgery department for close follow-up. Acetylsalicylic acid was stopped. Considering this first bleeding episode, the non-exophytic character of the pontine hemorrhage, and the mild degree of disability of the patient (Glasgow Outcome Scale [GOS] of 5), a conservative management was decided in the first place. The option of stereotactic radiosurgery was deemed unnecessary at the acute phase and in the setting of a first bleeding. Five months later, the patient was admitted for recurrence of the symptoms with a grade V HouseBrackman peripheral facial palsy and complete abducens nerve palsy on the left side, associated with contralateral face-sparing paresthesia. The CT scan of the brain showed evidence of rebleeding. After 2 weeks of close monitoring in the intensive care unit, surgical excision of the BCM was performed. The patient was operated on in a right park-bench position, the head being slightly rotated on the right to better expose the left side of the posterior fossa. Following a median incision and a median posterior fossa craniotomy, a telovelar approach was used to gain access to the rhomboid fossa. The exophytic hematoma appeared clearly on the left side at the level of the striae medullares, thus enabling us to remove the hematoma and the adjoining cavernoma through the infrafacial triangle. The DVA was left intact (Figs. 3, 4, Video 2). The postoperative course was complicated by a surgical site infection requiring surgical revision, placement of a temporary external ventricular drain and combined antibiotic therapy (meropenem and linezolid). The patient suffered from a left-sided grade VI House-Brackmann peripheral facial nerve palsy, further complicated by a corneal ulcer which was managed with local treatment. He also presented postoperatively with a non-pre-existing left-sided glossopharyngeal nerve (CN IX) palsy responsible for dysphagia and aspiration pneumonia, requiring a temporary gastroplasty. The patient was finally sent to neurological rehabilitation 3 months after the procedure.

\section{Discussion}

\section{Scope of the review}

In the light of this case report, our aim was to evaluate the proportion of CBS caused by hemorrhagic BCMs. We purposely chose to restrict the search to the five most frequent and widely recognized CBS, namely Benedikt (paramedian midbrain syndrome), Weber (superior

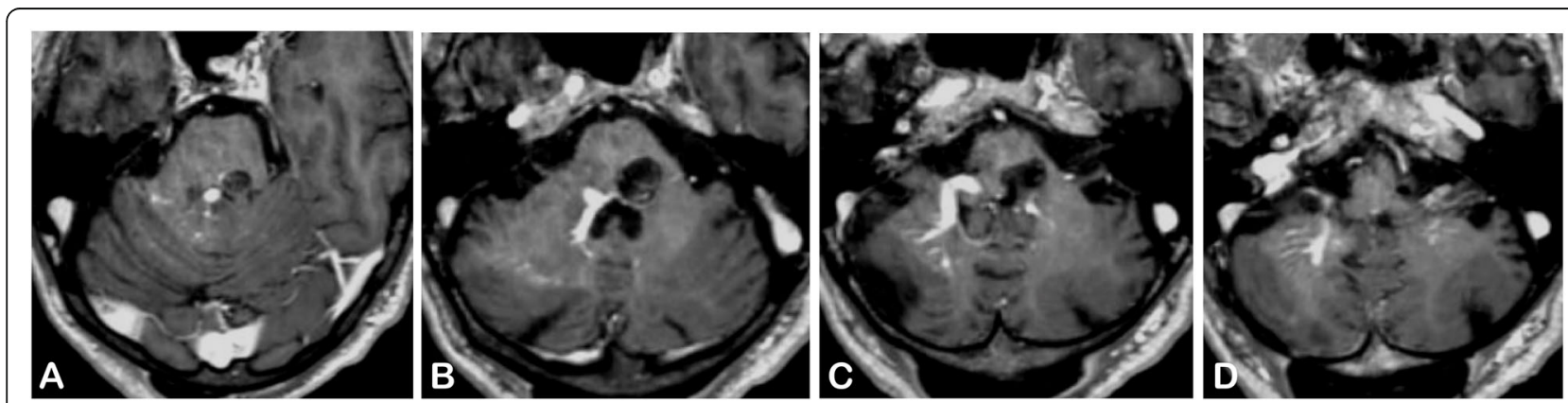

Fig. 3 Postoperative MRI of the brain in post-contrast T1-weighted sequence. We performed (d) a suboccipital telovelar approach to gain access to the rhomboid fossa. Then we used (c) the infrafacial triangle as an entry point to the pons to perform microsurgical excision of (a) the BCM and $(\mathbf{b}, \mathbf{c})$ the pontine hematoma. $\mathbf{a}, \mathbf{b}, \mathbf{c}, \mathbf{d}$ The DVA was left intact 


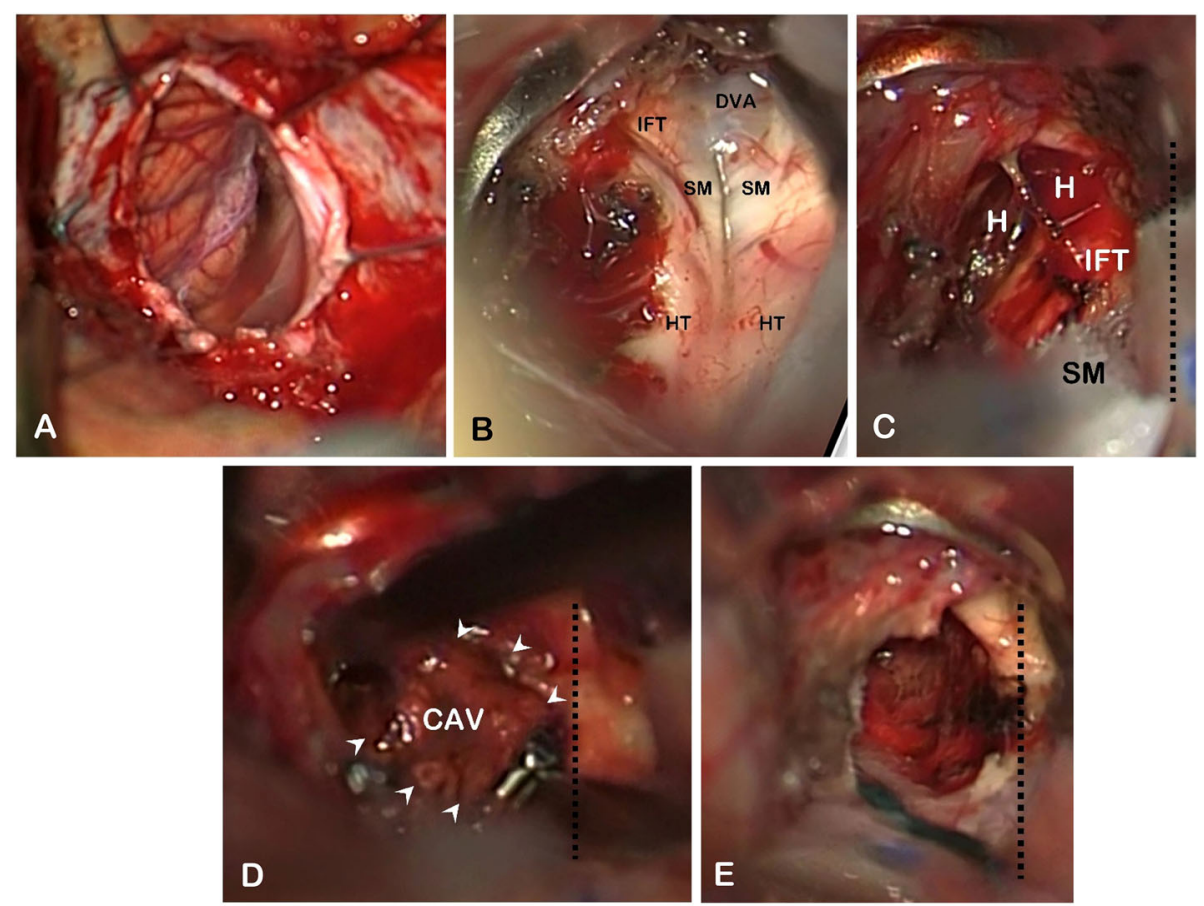

Fig. 4 Important surgical sequences. a Hockey stick fashion opening of the dura mater, discovering the cerebellar notch medially, and the left superior and inferior semilunar lobules. b The floor of the fourth ventricle appears after passing through the inferior medullary velum, and displays crucial anatomical landmarks such as the striae medullares (SM), the infrafacial triangle (IFT) just above and the hypoglossal triangle (HT) underneath. The exophytic hematoma appears clearly on the left side at the level of the striae medullares. The cerebellar developmental venous anomaly (DVA) appears in blue under a thin layer of nervous tissue. c Evacuation of the pontine hematoma (H) at the level of the infrafacial triangle (IFT), just above the striae medullares (SM) The midline is marked with a dotted line. $\mathbf{d}$ En-bloc excision of the cavernous malformation (CAV) using a tumor's clamp. e Resection cavity

alternating hemiplegia), Foville (inferior medial pontine syndrome), Millard-Gubler (ventral pontine syndrome), and Wallenberg (lateral medullary syndrome) syndromes.

\section{Database research}

We conducted a comprehensive literature review on Medline database (https://pubmed.ncbi.nlm.nih.gov/) from inception to 2020. We used the advanced search mode with the following Mesh terms in the title or in the text: Benedikt, Weber, Foville, Millard-Gubler, Wallenberg.

\section{Inclusion and exclusion criteria}

In the first instance, all the articles describing a CBS were retained regardless of the language and were screened in a systematic manner. The following information was extracted as previously planned: author, year, patient's age, name of the crossed brainstem syndrome, and etiology. When the full text was not available, the abstract was analyzed in search of the same information. Exclusion criteria consisted in articles with no genuine or dubious CBS, no patient's age, or no clear reference as to the underlying etiology.

\section{Results of database research}

The primary database research yielded 234 articles, among which 168 met the exclusion criteria after careful reading of the text or the abstract. Sixty-six articles were finally retained for a total of 69 patients [2]. There were 14 cases of Benedikt syndrome [3], three cases of Weber syndrome [4], 15 cases of Foville syndrome [5], nine cases of Millard-Gubler syndrome [6, 7], and 28 cases of Wallenberg syndrome [8] (Table 1).

\section{Causes of crossed brainstem syndromes}

At the level of the midbrain, Benedikt syndrome was usually caused by ischemic stroke $(n=6 / 14)$, followed by hemorrhage $(n=4 / 14)$ and direct nervous compression $(n=3 / 14)$ [9-22]. Weber syndrome was mainly caused by hemorrhage $(n=1 / 3)$ or infectious etiologies $(n=2 / 3)$ $[4,23,24]$. At the level of the pons, Foville syndrome was frequently caused by hemorrhage $(n=8 / 15)$, followed by ischemic stroke $(n=4 / 15)$ and brain metastases $(n=2 / 15)$ [25-37]. Conversely, Millard-Gubler syndrome was mostly related to an ischemic stroke $(n=7$ / $9)$, and rarely brought about by hemorrhage $(n=1 / 9)$ or brain abscess $(n=1 / 9)$ [38-46]. At the level of the medulla oblongata, Wallenberg syndrome was 


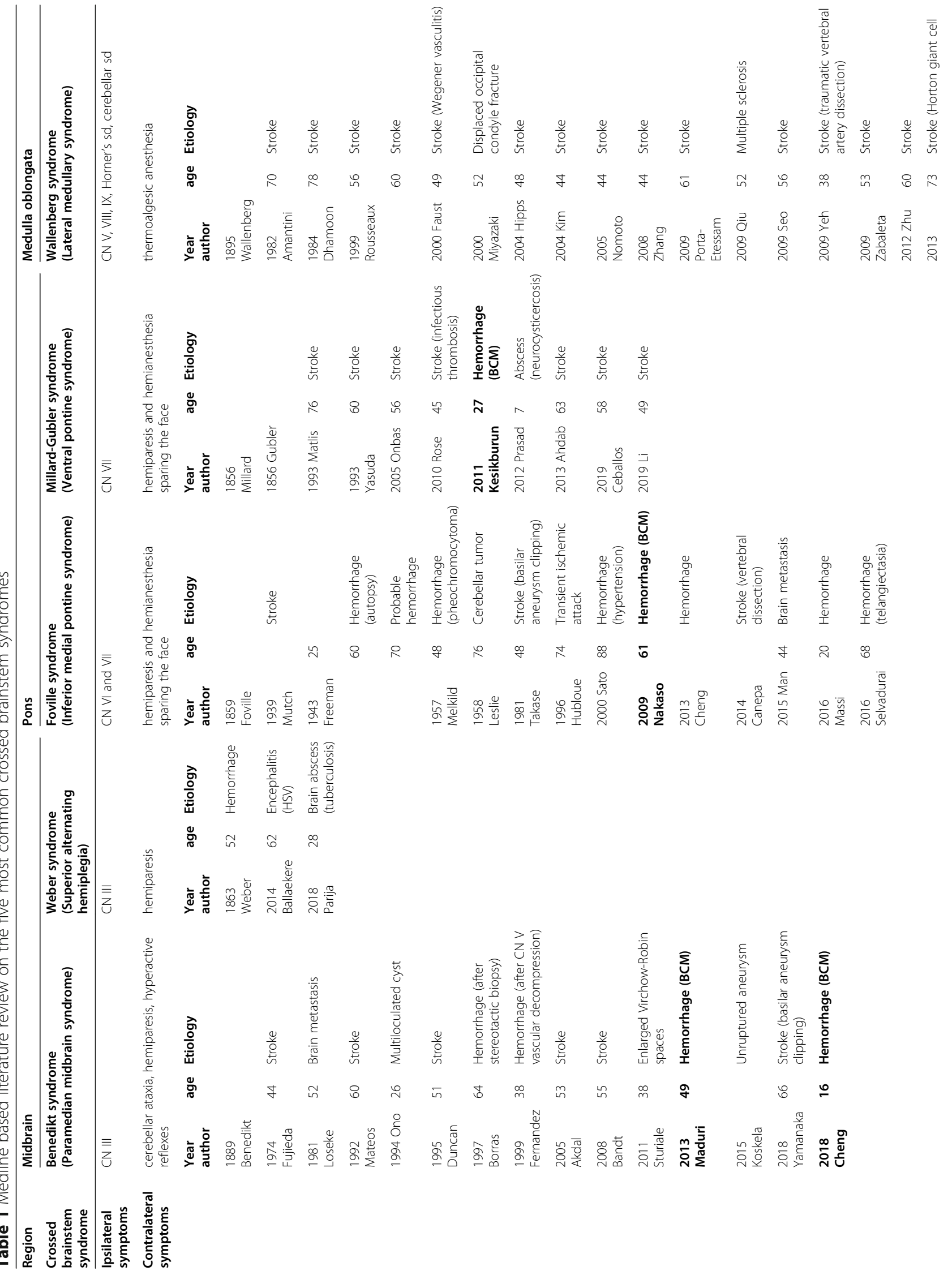




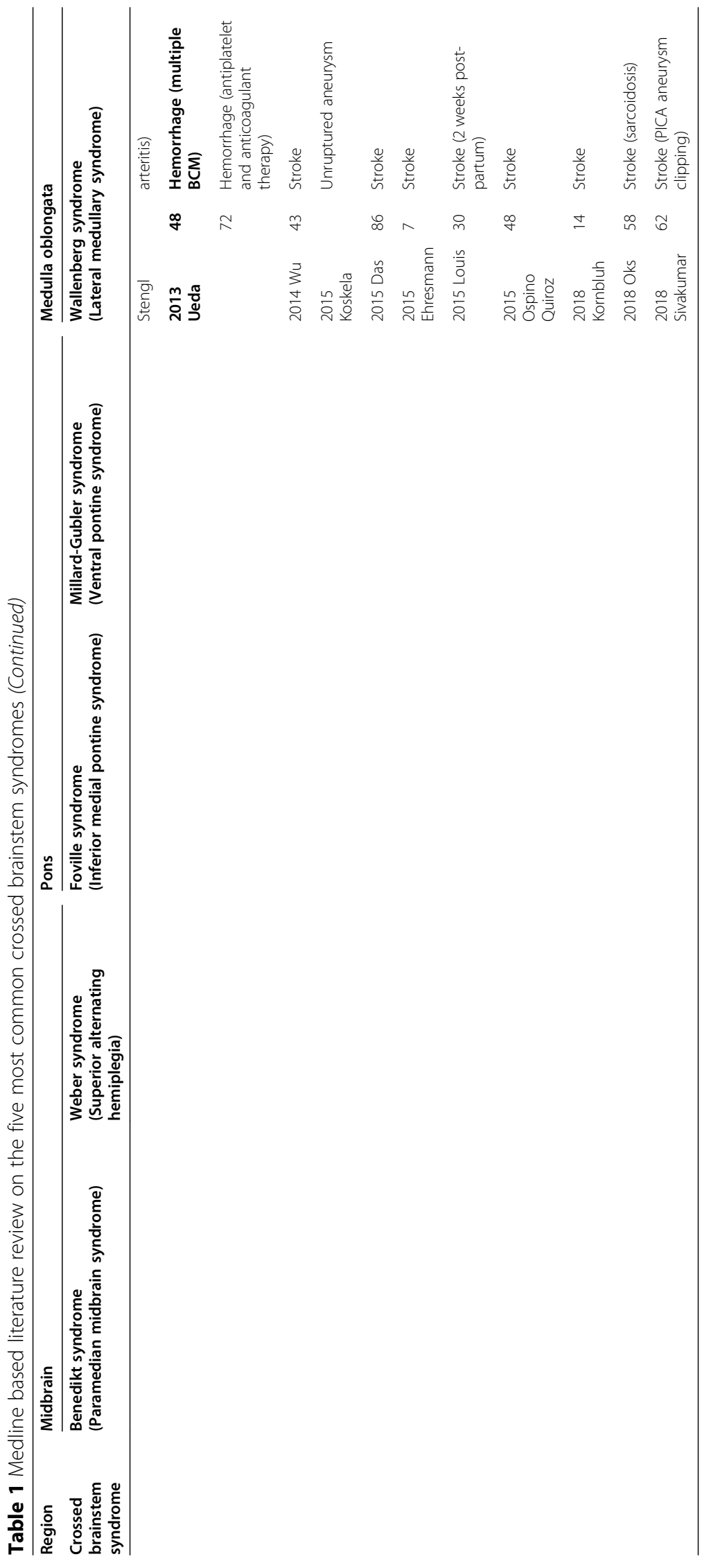


predominantly caused by ischemic stroke $(n=23 / 28)$, more rarely by hemorrhage $(n=2 / 28)$ or multiple sclerosis $(n=1 / 28)$ [18, 47-71]. The complete data is provided in Table 2.

Brainstem hemorrhage was responsible for approximately one quarter of the cases of CBS $(n=15 / 66)$. As for the underlying condition responsible for the brainstem bleeding, hypertension was the most frequently encountered etiology $(n=6 / 15)$, closely followed by $\operatorname{BCM}(n=5 / 15)$. Extralesional bleeding arising from $\mathrm{BCM}$ was responsible for one-seventh of the cases of Benedikt syndrome $(n=2 / 14)$, one out of ten cases of Millard-Gubler syndrome $(n=1 / 9)$, one-fifteenth of the cases of Foville syndrome $(n=1 / 15)$, and approximately one out of thirty cases of Wallenberg syndrome $(n=1$ / 28). There was also one case of Foville syndrome caused by a hemorrhage imputed to a telangiectasia.

It is to note that posterior circulation aneurysms were frequently encountered in this review $(n=5 / 69)$. Two unruptured aneurysms were responsible for nervous compression, the first one (probably arising from the posterior communicating artery) leading to a case of Benedikt syndrome and the second one (arising from the posterior inferior cerebellar artery) at the origin of a Wallenberg syndrome. Three aneurysms clipping resulted in infarction of perforating arteries, causing respectively a Benedikt syndrome, a Foville syndrome, and a Wallenberg syndrome.

Similarly, two cases of Benedikt syndrome were caused by a midbrain hematoma which occurred immediately after a neurosurgical procedure: one was secondary to a third ventricle tumor biopsy, and the other one was secondary to microvascular decompression for trigeminal neuralgia.

\section{Physiopathology of cerebral cavernous malformations}

Cerebral cavernous malformations (CCM) are mulberrylike fragile vascular malformations that are encountered in the cerebral hemispheres, brainstem and cerebellum, or in the spinal cord. Their structure consists in endothelial lined vascular sinusoids with no tight junctions and even gaps between the endothelial cells, forming

Table 2 Etiologies reported for the five most common crossed brainstem syndromes

\begin{tabular}{|c|c|c|c|c|c|c|}
\hline & Total & Benedikt & Weber & Foville & Millard-Gubler & Wallenberg \\
\hline Total & 69 & 14 & 3 & 15 & 9 & 28 \\
\hline Stroke & 40 & 6 & 0 & 4 & 7 & 23 \\
\hline Embolic event & 30 & 5 & & 1 & 6 & 18 \\
\hline Aneurysm clipping & 3 & 1 & & 1 & & 1 \\
\hline Artery dissection & 2 & & & 1 & & 1 \\
\hline Transient ischemic attack & 1 & & & 1 & & \\
\hline Vasculitis & 2 & & & & & 2 \\
\hline Infectious thrombosis & 1 & & & & 1 & \\
\hline Sarcoidosis & 1 & & & & & 1 \\
\hline Hemorrhage & 16 & 4 & 1 & 8 & 1 & 2 \\
\hline Hypertension & 6 & & & 6 & & \\
\hline Brainstem cavernous malformation & 5 & 2 & & 1 & 1 & 1 \\
\hline Telangiectasia & 1 & & & 1 & & \\
\hline Post-operative complication & 2 & 2 & & & & \\
\hline Anticoagulant therapy & 1 & & & & & 1 \\
\hline Compression & 5 & 3 & & & & 2 \\
\hline Unruptured aneurysm & 2 & 1 & & & & 1 \\
\hline Cyst / Virchow-Robin spaces & 2 & 2 & & & & \\
\hline Occipital fracture & 1 & & & & & 1 \\
\hline Brain metastasis & 3 & 1 & & 2 & & \\
\hline Infection & 3 & & 2 & & 1 & \\
\hline Brain abscess & 2 & & 1 & & 1 & \\
\hline Encephalitis & 1 & & 1 & & & \\
\hline Multiple sclerosis & 1 & & & & & 1 \\
\hline Unknown & 1 & & & 1 & & \\
\hline
\end{tabular}




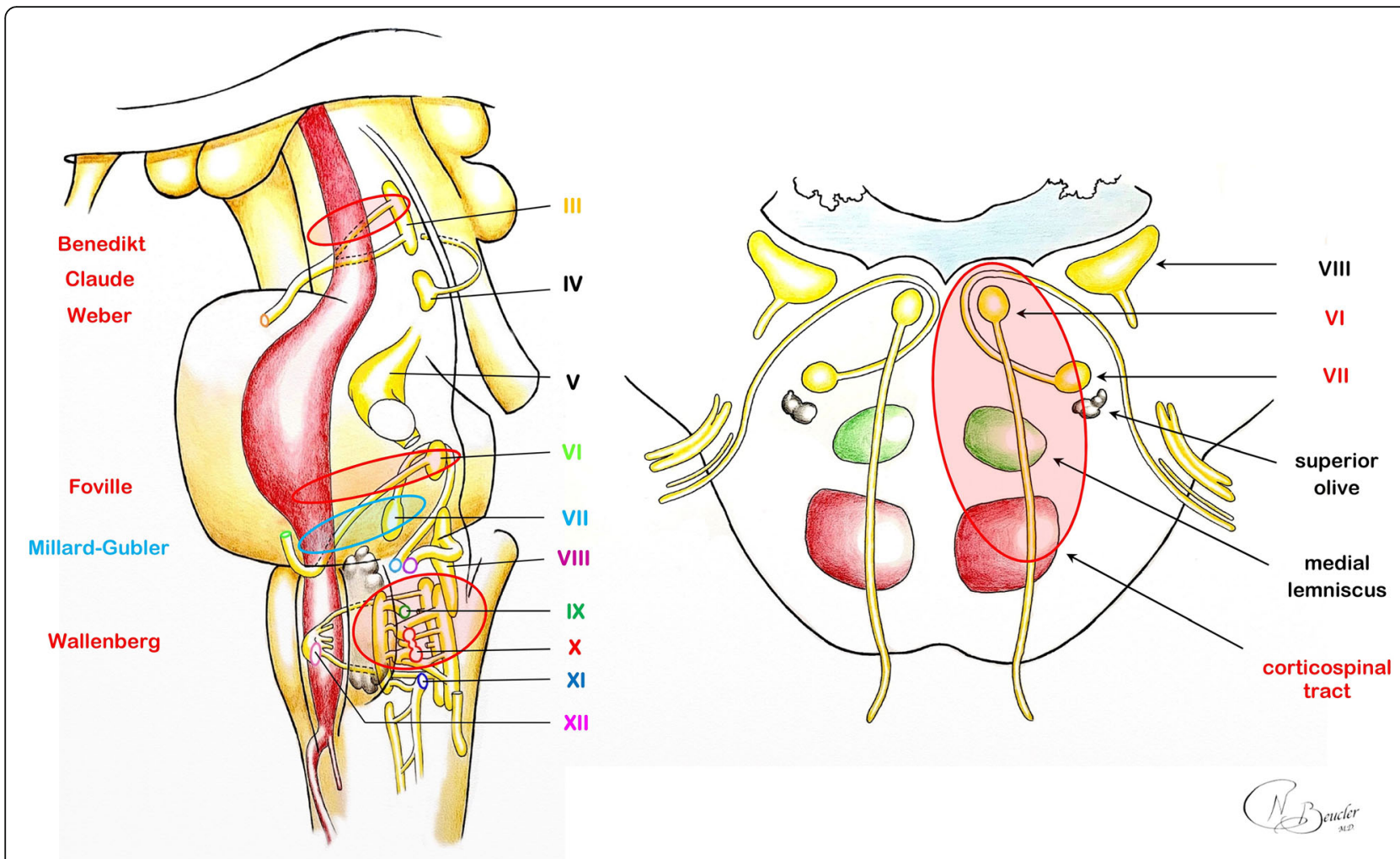

Fig. 5 (Left side) The artistic view of the brainstem shows that the corticospinal tract (red) shares intimate relations with the cranial nerve nuclei and fibers. (Right side) The artistic view of the inferior pons highlights the crossed neurological symptoms observed in the syndrome of Foville. The artistic views were drawn by Dr. Nathan BEUCLER

caverns within a dense collagen matrix clustered without intervening normal parenchyma [72].

CCM are often associated with venous drainage anomalies, ranging from solitary trans-cerebral or subpial draining veins to genuine DVAs [73]. DVA constitute an extreme anatomical variation draining normal cerebral tissue into an extra-parenchymatous collector; they reflect a variation of the well-known anastomosis between the superficial and the deep venous drainage systems of the brain which respond to a hemodynamic equilibrium [74].

The combination of inherently fragile sinusoids walls in the absence of blood-brain barrier and DVAs with raised venous pressure results in repeated intralesional micro hemorrhages which, in turn, leads to neoangiogenesis [75]. This "hemorrhagic angiogenic proliferation" mechanism results over time in the self-sustained growth of CCM, which is why they appear on neuroimaging as multilobulated vascular and calcified "popcorn" lesions as the type 2 described by Zabramski [76]. Although half of the CCM are discovered incidentally on neuroimaging, the other half may cause seizures related to the hemosiderin deposit around the lesion causing cortical irritation (25\%), focal neurological symptoms related to mass effect (15\%), or intracranial hemorrhage $(\mathrm{ICH})(12 \%)$ [77].

\section{Specific considerations for brainstem CCM}

It comes as no surprise that in the brainstem the most feared complication of CCM turns out to be bleeding which is also the main indication of excisional surgery [78]. The two main risk factors for the occurrence of an $\mathrm{ICH}$ ascribable to a CCM are history of a previous bleeding episode and the location in the brainstem [79]. Indeed, the estimated 5-year risk of $\mathrm{ICH}$ for an untreated $\mathrm{CCM}$ is $3.8 \%$ in case of non-brainstem CCM without $\mathrm{ICH}$ or $\mathrm{FND}, 8 \%$ in case of $\mathrm{BCM}$ without $\mathrm{ICH}$ or FND, $18.4 \%$ for non-brainstem CCM with $\mathrm{ICH}$ or FND, and increases up to $30.8 \%$ for $\mathrm{BCM}$ with $\mathrm{ICH}$ or FND [80]. In the brainstem, the estimated annual rate of extralesional bleeding is $8.7 \%$ for asymptomatic CCM, and rises to $12.4 \%$ for $\mathrm{CCM}$ with asymptomatic $\mathrm{ICH}$, and up to $15.9 \%$ for CCM with symptomatic ICH [81].

\section{Relevant surgical anatomy of the pons}

At the middle pons, corticospinal tract fibers are scattered anteriorly; motor neurons transit through transverse pontine fibers to merge the contralateral pontine nuclei and then join the middle cerebellar peduncle. The spinothalamic tract is located just posteriorly and lies within the medial lemniscus. The floor of the fourth ventricle provides a few surface reliefs that constitute 
important landmarks for neurosurgeons. The medial sulcus is bordered by the medial longitudinal fasciculi on both sides. The nucleus of the facial nerve is located laterally at the inferior part of the pons. The fibers of the future CN VII loop superiorly and medially around the abducens nerve nucleus. This peculiar anatomical configuration creates a bulging within the floor of the fourth ventricle known as the facial colliculus. Inferiorly, the striae medullares define the superior limit of the hypoglossal (CN XII), ambiguous (CN IX, X, XI) and vagus (CN X) nuclei. Pontine arterial supply is mainly anterior and lateral; no major artery is to be found near the floor of the fourth ventricle floor (Fig. 5).

\section{Surgical approaches to the pons}

The facial colliculus along with the fibers of future $\mathrm{CN}$ VII represent an important surgical landmark within the rhomboid fossa. They constitute the inferior limit of the suprafacial triangle which superior border are the superior and the middle cerebellar peduncles. On the same way, they constitute the superior limit of the infrafacial triangle which inferior borders are the striae medullares. These two triangles are known to be relatively safe entry corridors entry corridors for a surgical approach to the floor of the fourth ventricle as only scarce nerve fibers are encountered there $[82,83]$.

\section{Surgical considerations for brainstem cavernous malformations}

Recent literature does not provide sufficient evidence regarding the optimal timing for the surgical excision of a brainstem CCM with symptomatic extralesional bleeding, which is still a matter of debate. Zaidi et al. presented a series of 397 patients operated on for brainstem CCM, among which $96 \%$ percent presented history of prior ICH [84]. Thirty-five percent of the patients presented persistent postoperative neurological deficits (mainly $\mathrm{CN}$ deficits), and the mean GOS was unchanged at last follow-up compared with the GOS upon admission (4.47 vs 4.46 , median follow-up 35.5 months). They reported that early surgery within 6 weeks after ICH and smaller lesion size were associated with improved outcome. Garcia et al. presented a series of 104 patients operating on for brainstem CCM, among which 99\% presented history of prior ICH [85]. The mean modified Rankin scale upon admission was 2.23 compared to 1.58 at final follow-up. The most frequent perioperative complications were cerebrospinal fluid leakage (12.5\%), infection (9.6\%) and surgical site hematoma (6\%). Older age, large size lesions, lesions crossing the midline, delay between last bleeding event and surgery, and the association with a DVA were associated with a poorer prognosis.
Based on these retrospective series, surgical excision of a BCM may be deemed reasonable soon after the second symptomatic bleeding. In such case, the high operative morbidity inherent to brainstem surgery is warranted by the aggressive natural course of the disease.

\section{Surgical considerations for associated developmental venous anomalies}

Until the 2000s, there have only been sporadic reports on the treatment of DVA. Some reported cases supported the surgical excision of the DVA [86, 87], whereas intraoperative complications such as brain swelling after DVA coagulation have been reported [88]. Campeau et al. neuro-imaging study seemed to confirm the hypothesis that repeated microbleeding episodes and neoangiogenesis led to the formation of CCM in the vicinity of DVA [89]. In accordance with that theory, Wurm et al. reported a series of 15 patients who benefited from microsurgical excision of a CCM [90]. The associated DVA was coagulated in six patients and left intact in nine of them. Three patients from the group with intact DVA presented the recurrence of a CCM and benefited from a second microsurgical excision with simultaneous coagulation of the DVA. The authors did not report any venous complication in the patients who benefited from the treatment of the DVA, with a mean follow-up of 29 months. Nevertheless, this series, made up of only 15 patients, lacks long-term follow-up. Besides, six patients whose DVA had been left intact did not present recurrence of CCM. More recent reports continue to support the elective microsurgical excision of symptomatic CCM without touching the associated DVA [91]. Venous sacrifice in cranial neurosurgical procedures has always been considered hazardous for fear of the potential disastrous consequences of venous infarction [92, 93], which are very difficult to predict [94]. Consequently, we tend to recommend leaving the DVA intact during the microsurgical excision of CCM.

\section{Specific considerations for crossed pontine syndromes}

The specific vascular supply of the pons may explain the difference of etiology that we have observed between Foville syndrome (the inferior medial pontine syndrome) and Millard-Gubler syndrome (the ventral pontine syndrome). Pontine hemorrhage caused by high blood pressure is usually located more medially and damages both CN VI nucleus and CN VII fibers, leading to Foville syndrome. By contrast, ischemic stroke involves rather the paramedian branches or the short circumferential branches of the basilar artery which supply more lateral structures such as CN VII nucleus, leading thus to Millard-Gubler syndrome [95].

If we closely examine the clinical nuances reported throughout the history concerning Foville syndrome, the 


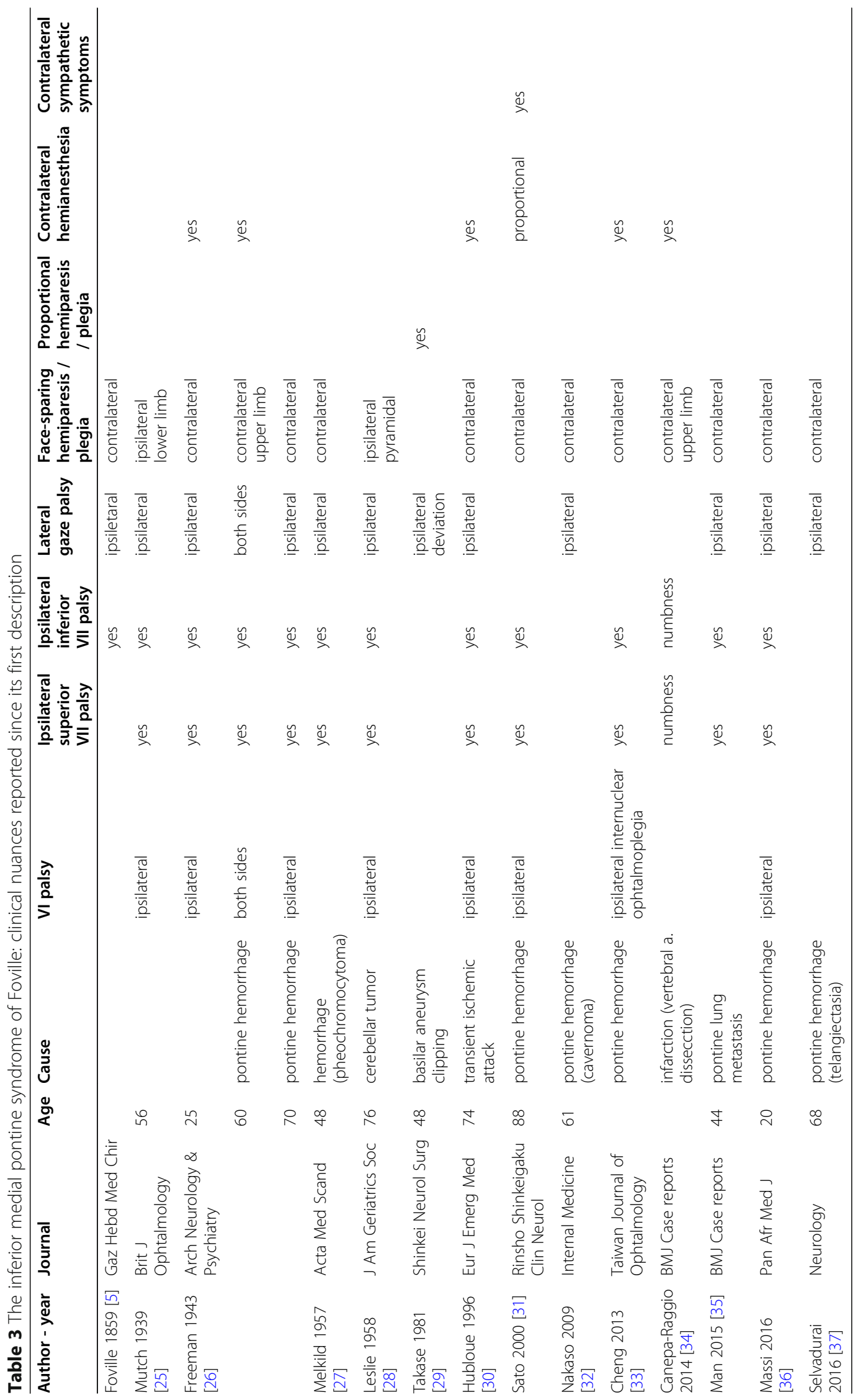


different forms of oculomotor palsies that were observed led to the distinction between a "superior Foville syndrome" characterized by the presence of a CN VI palsy and an "inferior Foville syndrome" with lateral conjugate gaze palsy due to the involvement of the medial longitudinal fasciculus or the paramedian pontine reticular formation (Table 3).

\section{Limitations of the study}

This review presents some limits inherent to its retrospective nature. Purposely or not case reports unconsciously select patients with favorable outcome; thus, their compilation may lead to a reporting bias which may underestimate the mortality rate. The literature review was deliberately restricted to the five most common CBS which may constitute a limit but still enabled us to collect a great number of articles. To the best of our knowledge, this is the first study attempting to provide a clear and updated picture of the proportion of BCMs responsible for or revealed by a genuine CBS.

\section{Conclusions}

Pure crossed brainstem syndromes are rarely encountered in clinical practice. They remarkably illustrate the anatomical peculiarity of the brainstem, which represents a crossroad between the cranial nerves, the long tracts and key vegetative structures. In the light of this review, brainstem cavernous malformations with extralesional bleeding appear to account for approximately $7 \%$ of all crossed brainstem syndromes. The indication and timing of the surgical excision of a symptomatic brainstem cavernous malformation remains a complex decision to make and requires multidisciplinary team expertise. It has to be discussed openly between neurosurgeons and their patient, taking into consideration the existing evidence in favor of surgery but also the substantial risks associated with such a delicate procedure. Multicentric prospective trials will be very difficult to conduct on such rare entities. Robust knowledge in brainstem anatomy along with thorough neurological examination skills will remain pivotal to the initial management of these patients.

\section{Supplementary Information}

The online version contains supplementary material available at https://doi. org/10.1186/s12883-021-02223-7.

Video 1

Video 2

Acknowledgements

None.

\section{Authors' contributions}

$\mathrm{NB}$ and $\mathrm{HD}$ conceptualized the article. NB, SB, AR, SF, RC, HD participated to the literature review. NB, SB, AR, SF, RC, HD participated to the clinical care of the patient. NB, SB, AR, SF, RC, HD participated to the drafting of the manuscript. NB, RC, HD participated to the critical revision of the manuscript. All authors have read and approved the manuscript.

\section{Funding}

The authors did not receive any funding for this work. The publication charges of this article were gracefully covered by the "neuro-oncology and neuro-endocrinology research group" (Grenone) of Timone University Hospital, 13010 Marseille, France.

Availability of data and materials

All the relevant data is included in the manuscript. There is no data deposit for this work.

\section{Declarations}

\section{Ethics approval and consent to participate}

Informed written consent was obtained from the patient whose case report is included in the manuscript. He has been given the opportunity to review the manuscript and the attached files. This work was conducted in accordance with the Declaration of Helsinki of 1964 or its further amendments (2013).

\section{Consent for publication}

Written informed consent was obtained from the patient for the publication of this manuscript and any accompanying figure and video. A copy of the written consent is attached to the manuscript.

\section{Competing interests}

All authors certify that they have no affiliations with or involvement in any organization or entity with any financial interest (such as honoraria; educational grants; participation in speakers' bureaus; membership, employment, consultancies, stock ownership, or other equity interest; and expert testimony or patent-licensing arrangements), or non-financial interest (such as personal or professional relationships, affiliations, knowledge or beliefs) in the subject matter or materials discussed in this manuscript.

\section{Author details}

'Department of Neurosurgery, Timone University Hospital, APHM, 264 rue Saint-Pierre, 13005 Marseille, France. ${ }^{2}$ Ecole du Val-de-Grâce, French Military Health Service Academy, 1 place Alphonse Laveran, 75230 Paris Cedex 5,

France. ${ }^{3}$ Aix Marseille Univ, INSERM, INS, Inst Neurosci Syst, Marseille, France. ${ }^{4}$ Emergency Department, Timone University Hospital, APHM, 264 Rue Saint-Pierre, 13005 Marseille, France. ${ }^{5}$ Department of Stereotactic and Functional Neurosurgery, Timone University Hospital, APHM, 264 rue Saint-Pierre, 13005 Marseille, France. ${ }^{6}$ Aix-Marseille Univ, INSERM, MMG, Marseille, France.

Received: 7 December 2020 Accepted: 4 May 2021

Published online: 20 May 2021

\section{References}

1. Querol-Pascual MR. Clinical approach to brainstem lesions. Semin Ultrasound CT MRI. 2010;31(3):220-9. https://doi.org/10.1053/j.sult.2010. 03.004.

2. Marx JJ, Thömke F. Classical crossed brain stem syndromes: myth or reality? J Neurol. 2009;256(6):898-903. https://doi.org/10.1007/s00415-009-5037-2.

3. Benedikt M. lecture. 1889;

4. Weber H. A contribution to the pathology of the Crura Cerebri. J R Soc Med. 1863:MCT-46(1):121-39. https://doi.org/10.1177/095952876304600112.

5. Foville A. Note sur une paralysie peu connue de certains muscles de l'oeil et sa liaison avec quelques points de l'anatomie et la physiologie de la protubérance annulaire. Bull Soc Anat. (Paris). 1858;33:373-405.

6. Cenac H, Millard A. Hémorrhagie de la protubérance annulaire. Bull Soc Anat. (Paris). 1856;36:206-21.

7. Gubler A. De l'hémiplégie alterne envisagée comme signe de lésion de la protubérance annulaire et comme preuve de la décussation. Gaz Hebd Méd Chir. 1856;3(43):749-54. 
8. Wallenberg A. Akute Bulbäraffektion (Embolie der Arteria cerebelli post inf sinistra). Arch Psychiatry. 1895;27(2):504-40. https://doi.org/10.1007/BF02 075799

9. Fujieda T, Yamauchi T, Takahashi S, Moroji T. Letter: effect of levodopa on tremor in Benedikt's syndrome. Br Med J. 1974;1(5905):456-7. https://doi. org/10.1136/bmj.1.5905.456-b.

10. Loseke N, Retif J, Noterman J, Flament-Durand J. Inferior red nucleus syndrome (Benedikt's syndrome) due to a single intramesencephalic metastasis from a prostatic carcinoma. Case Rep Acta Neurochir (Wien). 1981;56(1-2):59-64.

11. Ono Y, Suzuki M, Kayama T, Yoshimoto T. Multilobulated cystic formation in the brain stem with Benedikt's syndrome: case report. Neurosurgery. 1994; 34(4):726-9 discussion 729

12. Borrás JM, Salazar FG, Grandas F. Oculomotor palsy and contralateral tremor (Benedikt's syndrome) following a stereotactic procedure. J Neurol. 1997; 244(4):272-4. https://doi.org/10.1007/s004150050085.

13. Fernandez HH, Friedman JH, Centofanti JV. Benedikt's syndrome with delayedonset rubral tremor and hemidystonia: a complication of tic douloureux surgery. Mov Disord Off J Mov Disord Soc. 1999;14(4):695-7. https://doi.org/1 0.1002/1531-8257(199907)14:4<695::AID-MDS1024>3.0.CO;2-3.

14. Akdal G, Kutluk K, Men S, Yaka E. Benedikt and "plus-minus lid" syndromes arising from posterior cerebral artery branch occlusion. J Neurol Sci. 2005; 228(1):105-7. https://doi.org/10.1016/j.jns.2004.09.029.

15. Bandt SK, Anderson D, Biller J. Deep brain stimulation as an effective treatment option for post-midbrain infarction-related tremor as it presents with Benedikt syndrome. J Neurosurg. 2008;109(4):635-9. https://doi.org/1 0.3171/JNS/2008/109/10/0635.

16. Sturiale CL, Albanese A, Lofrese G, Frassanito P, Sabatino G, Marchese E, et al. Pathological enlargement of midbrain Virchow-Robin spaces: a rare cause of obstructive hydrocephalus. Br J Neurosurg. 2011;25(1):130-1. https://doi.org/10.3109/02688697.2010.504050.

17. Maduri R, Barbagallo G, lofrida G, Signorelli M, Signorelli F. Regression of Benedikt's syndrome after single-stage removal of mesencephalic cavernoma and temporal meningioma: a case report. Clin Neurol Neurosurg. 2013;115(6):748-50. https://doi.org/10.1016/j.clineuro.2012.06.033.

18. Koskela E, Setälä K, Kivisaari R, Hernesniemi J, Laakso A. Neuro-ophthalmic presentation and surgical results of unruptured intracranial aneurysms - prospective Helsinki experience of 142 patients. World Neurosurg. 2015;83(4):614-9. https://doi.org/10.1016/j.wneu.2014.12.017.

19. Cheng $G$, Yang $Y$, Wang $Y$, Tan $H$, Zhang $S$. Deep brain stimulation of the thalamic ventral intermediate nucleus for Benedikt's syndrome mainly present as tremor: a long-term case observation. Acta Neurochir. 2018; 160(7):1349-53. https://doi.org/10.1007/s00701-018-3526-8.

20. Mateos V, Campos DM, Colosía VP, Salas-Puig J, Fernández JM, Lahoz CH. Nuclear syndrome of the oculomotor nerve caused by a mesencephalic infarction confirmed by MRI. Arch Neurobiol (Madr). 1992;55(4):183-7.

21. Duncan GW, Weindling SM. Posterior cerebral artery stenosis with midbrain infarction. Stroke. 1995;26(5):900-2. https://doi.org/10.1161/01.STR.26.5.900.

22. Yamanaka Y, Shinohara T, Kozano I, Yoshizumi T, Kawasaki T. Benedikt syndrome associated with neck clipping of ruptured basilar-superior cerebellar artery aneurysm:a case report. No Shinkei Geka. 2018;46(11):100712. https://doi.org/10.11477/mf.1436203855.

23. Ballaekere JS, Chebbi PP, Sundarmurthy H, Parameshwarappa A. Weber syndrome: herpes simplex virus brainstem encephalitis as an etiology. Am J Med. 2014;127(12):e5-6. https://doi.org/10.1016/j.amjmed.2014.08.005.

24. Parija S, Lalitha CS, Naik $S$. Weber syndrome secondary to brain stem tuberculoma. Indian J Ophthalmol. 2018;66(7):1036-9. https://doi.org/10.41 03/ijo.IJO_1040_17.

25. Mutch JR. FOVILLE'S syndrome record of a CASE. Br J Ophthalmol. 1939; 23(4):225-38. https://doi.org/10.1136/bjo.23.4.225.

26. Freeman W, SYNDROMES OF, THE PONTILE TEGMENTUM. FOVILLE'S syndrome: report of three cases. Arch Neurol Psychiatr. 1943;50(4):462. https://doi.org/10.1001/archneurpsyc.1943.02290220092008.

27. Melkild A, Mörstad KS. Foville's syndrome as a complication of Phaeochromocytoma. Acta Med Scand. 1957;159(6):471-4. https://doi.org/1 0.1111/j.0954-6820.1957.tb00155.x

28. Levene $L$. Benign cerebellar tumor presenting a modified Foville syndrome. J Am Geriatr Soc. 1958;6(4):346-51. https://doi.org/10.1111/j.1532-5415.1958. tb00726.x
29. Takase M, Saeki N, Oka N, Satoh A, Otaki M, Yamaura A. Superior Foville syndrome after clipping of basilar bifurcation aneurysm--case report (author's transl). No Shinkei Geka. 1981;9(3):343-7.

30. Hubloue I, Laureys S, Michotte A. A rare case of diplopia: medial inferior pontine syndrome or Foville??s syndrome. Eur J Emerg Med. 1996;3(3):194-8

31. Sato K, Nitta E. Pontine hemorrhage presenting with Foville syndrome and transient contralateral hyperhidrosis. Rinsho Shinkeigaku. 2000;40(3):271-3.

32. Nakaso K, Sasaki K. Fluctuating Foville's syndrome caused by a pontine Angioma in a patient with a polycystic kidney. Intern Med. 2009;48(15): 1335-6. https://doi.org/10.2169/internalmedicine.48.2314.

33. Cheng $\mathrm{H}-\mathrm{C}$, Yen $\mathrm{M}-\mathrm{Y}$, Wang A-G. Foville's syndrome with ipsilateral internuclear ophthalmoplegia due to spontaneous pontine hemorrhage. Taiwan J Ophtalmol. 2013;3(2):75-7. https://doi.org/10.1016/j.tjo.2012.12.001.

34. Canepa Raggio C, Dasgupta A. Three cases of Spontaneous Vertebral Artery Dissection (SVAD), resulting in two cases of Wallenberg syndrome and one case of Foville syndrome in young, healthy men. Case Rep. 2014;2014(apr28 2):bcr2014203945.

35. Man BL, Fu YP. Bronchogenic carcinoma presented as Foville's syndrome. Case Rep. 2015;2015(mar03 2):bcr2014205025.

36. Massi DG, Nyassinde J, Ndiaye MM. Superior Foville syndrome due to pontine hemorrhage: a case report. Pan Afr Med J. 2016;25:215.

37. Selvadurai C, Rondeau MW, Colorado RA, Feske SK, Prasad S. Teaching video neuro Images : Foville syndrome. Neurology. 2016;86(19):e203. https://doi, org/10.1212/WNL.0000000000002658.

38. Matlis A, Kleinman Y, Korn-Lubetzki I. Millard-Gubler syndrome. AJNR Am J Neuroradiol. 1994;15(1):179-81.

39. Yasuda Y, Matsuda I, Sakagami T, Kobayashi H, Kameyama M. Pontine infarction with pure Millard-Gubler syndrome: precise localization with magnetic resonance imaging. Eur Neurol. 1993;33(4):333-4. https://doi.org/10.1159/000116965.

40. Onbas $\mathrm{O}$, Kantarci M, Alper F, Karaca L, Okur A. Millard-Gubler syndrome: MR findings. Neuroradiology. 2005;47(1):35-7. https://doi. org/10.1007/s00234-004-1312-1.

41. Rose DZ, Parra-Herran C, Petito CK, Post MJD. Restricted diffusion of pus in the subarachnoid space: MRSA Meningo-Vasculitis and progressive brainstem ischemic strokes - a case report. Case Rep Neurol. 2010;2(2):10110. https://doi.org/10.1159/000319691.

42. Kesikburun S, Safaz I, Alaca R. Pontine cavernoma hemorrhage leading to millard-gubler syndrome. Am J Phys Med Rehabil. 2011;90(3):263. https:// doi.org/10.1097/PHM.0b013e3181e29e8e.

43. Prasad R, Kapoor K, Mishra OP, Srivastava A. Neurocysticercosis presenting as Millard Gubler syndrome. J Neurosci Rural Pract. 2012;03(03):375-7.

44. Ahdab R, Saade HS, Kikano R, Ferzli J, Tarcha W, Riachi N. Pure ipsilateral central facial palsy and contralateral hemiparesis secondary to ventromedial medullary stroke. J Neurol Sci. 2013;332(1-2):154-5. https://doi.org/1 0.1016/j.jns.2013.06.028.

45. Ceballos-Lizarraga R, Palomino-Díaz C, Romero-Figueroa JÁ. Wall-eyed monocular Internuclear Ophthalmoplegia (WEMINO) and Millard-Gubler syndromes in a patient with isolated pontine infarction: topographic, oculomotor, and radiological analysis of two very uncommon conditions. Case Rep Neurol. 2019;11(2):230-7. https://doi.org/10.1159/000501794.

46. Li X-T, Yuan J-L, Hu W-L. Vertebrobasilar artery dissection manifesting as Millard-Gubler syndrome in a young ischemic stroke patient: a case report. World J Clin Cases. 2019;7(1):73-8. https://doi.org/10.12998/wjcc.v7.i1.73.

47. Amantini A, Arnetoli G, Rossi L, Fenzi, Salviati A, Rizzuto N, et al. BAEP and autopsy findings in Wallenberg syndrome. Ital J Neurol Sci. 1982;3(3):237-40. https://doi.org/10.1007/BF02043316.

48. Dhamoon SK, lqbal J, Collins GH. Ipsilateral hemiplegia and the Wallenberg syndrome. Arch Neurol. 1984;41(2):179-80. https://doi.org/10.1001/a rchneur.1984.04050140077029.

49. Rousseaux M, Cassim F, Bayle B, Laureau E. Analysis of the perception of and reactivity to pain and heat in patients with Wallenberg syndrome and severe spinothalamic tract dysfunction. Stroke. 1999;30(10):2223-9. https:// doi.org/10.1161/01.STR.30.10.2223.

50. Faust J, Visbeck A, Fitzek S, et al. Vasculitic wallenberg syndrome with detection of anti-proteinase 3 antibodies in the cerebrospinal fluid of a patient with severe Wegener's granulomatosis and only mild kidney involvement. Nephrol Dial Transplant Off Publ Eur Dial Transpl Assoc Eur Ren Assoc. 2000;15(6):893-6.

51. Miyazaki C, Katsume M, Yamazaki T, Aoki K, Kuroki T, Takasu N. Unusual occipital condyle fracture with multiple nerve palsies and Wallenberg 
syndrome. Clin Neurol Neurosurg. 2000;102(4):255-8. https://doi.org/10.101 6/S0303-8467(00)00109-8.

52. Hipps WM, Wilhelmus KR. Persistent visual loss from neurotrophic corneal ulceration after dorsolateral medullary infarction (Wallenberg syndrome). J Neuroophthalmol. 2004;24(4):345-6. https://doi.org/10.1097/00041327-2 00412000-00015.

53. Kim JS, Moon SY, Park S-H, Yoon B-W, Roh J-K. Ocular lateropulsion in Wallenberg syndrome. Neurology. 2004;62(12):2287. https://doi.org/10.1212/ WNL.62.12.2287

54. Nomoto N, Konno S, Sugimoto H, Kurihara T, Wakata N. Wallenberg syndrome with SIADH. Eur Neurol. 2005;53(1):35-6. https://doi.org/10.1159/ 000084260 .

55. Zhang S-Q, Liu M-Y, Wan B, Zheng H-M. Contralateral body half Hypalgesia in a patient with lateral medullary infarction: atypical Wallenberg syndrome. Eur Neurol. 2008;59(3-4):211-5. https://doi.org/10.1159/000114050.

56. Porta-Etessam J, Casanova I, Pajuelo B, di Capua D, del Val J, García García $M E$, et al. See-saw nystagmus in a patient with Wallenberg syndrome. J Neuroophthalmol. 2009;29(1):73-4. https://doi.org/10.1097/WNO.0b013e31 81989dc1.

57. Qiu W, Wu J-S, Carroll WM, Mastaglia FL, Kermode AG. Wallenberg syndrome caused by multiple sclerosis mimicking stroke. J Clin Neurosci. 2009;16(12):1700-2. https://doi.org/10.1016/j.jocn.2009.04.008.

58. Seo WK, Kwon DY, Seo SH, Park MH, Park KW. Neuropathic pruritus following Wallenberg syndrome. Neurology. 2009;72(7):676. https://doi.org/1 0.1212/01.wnl.0000342484.99298.52

59. Yeh H-F, Seak C-J, Chiu T-F, Chang Y-C. Traumatic vertebral artery dissection and Wallenberg syndrome after a motorcycle collision. Am J Emerg Med. 2009;27(1):131.e1-3.

60. Ayerbe Zabaleta I, Negrevergne M, Ucelay Vicinay I, Catherine M. Vértigo agudo pseudoperiférico y síndrome de Wallenberg. Acta Otorrinolaringológica Esp. 2010;61(4):312-4. https://doi.org/10.1016/j.otorri.2 009.06.001.

61. Zhu J, Li J, Liu Y, Han Y, Wang Y. Unilateral headache with visual Aura from a Wallenberg syndrome. CNS Neurosci Ther. 2012;18(7):598-600. https://doi. org/10.1111/j.1755-5949.2012.00330.x.

62. Stengl KL, Buchert R, Bauknecht H, Sobesky J. A hidden giant: Wallenberg syndrome and aortal wall thickening as an atypical presentation of a giant cell arteritis. Case Rep. 2013;2013(mar01 1):bcr2012006994.

63. Ueda M, Nishiyama Y, Abe A, Katayama Y. Hemorrhagic Wallenberg syndrome. Intern Med. 2013;52(20):2383-4. https://doi.org/10.2169/interna Imedicine.52.1141.

64. Wu S, Li N, Xia F, Sidlauskas K, Lin X, Qian Y, et al. Neurotrophic keratopathy due to dorsolateral medullary infarction (Wallenberg syndrome): case report and literature review. BMC Neurol. 2014;14(1):231. https://doi.org/10.1186/ s12883-014-0231-y.

65. Das P, Chopra A, Rai A, Kuppuswamy PS. Late-onset recurrent mania as a manifestation of Wallenberg syndrome: a case report and review of the literature. Bipolar Disord. 2015;17(6):677-82. https://doi.org/10.1111/ bdi.12318.

66. Ehresmann A, Van H, Merlini L, Fluss J. Wallenberg syndrome: an exceptional cause of acute Vertigo in children. Neuropediatrics. 2015;47(01): 061-3. https://doi.org/10.1055/s-0035-1566731.

67. Louis DW, Dholakia N, Raymond MJ. Wallenberg syndrome with associated motor weakness in a two-week-postpartum female. Case Rep Neurol. 2015; 7(3):186-90. https://doi.org/10.1159/000440712.

68. Ospino Quiroz JC, Monteagudo CJ. A propósito de un caso de síndrome de Wallenberg. SEMERGEN Med Fam. 2016;42(8):e179-80. https://doi.org/10.101 6/j.semerg.2015.10.012.

69. Kornbluh A, Twanow J-D. Teaching Neurolmages: adolescent Wallenberg syndrome with overlooked signs: Ipsipulsion and ipsilateral facial palsy. Neurology. 2018;91(20):e1949-50. https://doi.org/10.1212/WNL. 0000000000006513.

70. Oks M, Li A, Makaryus M, Pomeranz HD, Sachdeva M, Pullman J, et al. Sarcoidosis presenting as Wallenberg syndrome and panuveitis. Respir Med Case Rep. 2018;24:16-8. https://doi.org/10.1016/j.rmcr.2018.03.002.

71. Sivakumar K, Garcha M, Mehta D, Leary MC, Yacoub HA. Central hypoventilation: a rare complication of Wallenberg syndrome. Case Rep Neurol Med. 2018:2018:1-3.

72. Clatterbuck RE. Ultrastructural and immunocytochemical evidence that an incompetent blood-brain barrier is related to the pathophysiology of cavernous malformations. J Neurol Neurosurg Psychiatry. 2001;71 (2):188-92. https://doi.org/10.1136/jnnp.71.2.188.

73. Dammann P, Wrede KH, Maderwald S, el Hindy N, Mueller O, Chen B, et al. The venous angioarchitecture of sporadic cerebral cavernous malformations: a susceptibility weighted imaging study at 7 T MRI. J Neurol Neurosurg Psychiatry. 2013;84(2):194-200. https://doi.org/10.1136/jnnp-2 012-302599.

74. Lasjaunias P, Burrows P, Planet C. Developmental venous anomalies (DVA): the so-called venous angioma. Neurosurg Rev. 1986;9(3):233-42. https://doi. org/10.1007/BF01743138.

75. Pozzati E, Acciarri N, Tognetti F, Marliani F, Giangaspero F. Growth, subsequent bleeding, and De novo appearance of cerebral cavernous Angiomas. Neurosurgery. 1996;38(4):662-70. https://doi.org/10.1227/ 00006123-199604000-00006.

76. Zabramski JM, Wascher TM, Spetzler RF, Johnson B, Golfinos J, Drayer BP, et al. The natural history of familial cavernous malformations: results of an ongoing study. J Neurosurg. 1994;80(3):422-32. https://doi.org/10.3171/jns.1 994.80.3.0422.

77. Salman RA-S, Hall JM, Horne MA, et al. Untreated clinical course of cerebral cavernous malformations: a prospective, population-based cohort study. Lancet Neurol. 2012;11(3):217-24. https://doi.org/10.1016/S1474-4422(12)70004-2.

78. Al-Shahi Salman R, Berg MJ, Morrison L, Awad IA. Hemorrhage from cavernous malformations of the brain: definition and reporting standards. Stroke. 2008;39(12):3222-30. https://doi.org/10.1161/STROKEAHA.108.515544.

79. Akers A, Al-Shahi Salman R. A. Awad I, et al. synopsis of guidelines for the clinical Management of Cerebral Cavernous Malformations: consensus recommendations based on systematic literature review by the Angioma Alliance scientific advisory board clinical experts panel. Neurosurgery. 2017; 80(5):665-80. https://doi.org/10.1093/neuros/nyx091.

80. Horne MA, Flemming KD, Su I-C, Stapf C, Jeon JP, Li D, et al. Clinical course of untreated cerebral cavernous malformations: a meta-analysis of individual patient data. Lancet Neurol. 2016;15(2):166-73. https://doi.org/10.1016/S14 74-4422(15)00303-8.

81. Li D, Hao S-Y, Jia G-J, Wu Z, Zhang L-W, Zhang J-T. Hemorrhage risks and functional outcomes of untreated brainstem cavernous malformations. J Neurosurg. 2014;121(1):32-41. https://doi.org/10.3171/2014.3.JNS132537.

82. Kyoshima K, Kobayashi S, Gibo H, Kuroyanagi T. A study of safe entry zones via the floor of the fourth ventricle for brain-stem lesions: report of three cases. J Neurosurg. 1993;78(6):987-93. https://doi.org/10.3171/ jns.1993.78.6.0987.

83. Cavalcanti DD, Preul MC, Kalani MYS, Spetzler RF. Microsurgical anatomy of safe entry zones to the brainstem. J Neurosurg. 2016;124(5):1359-76. https:// doi.org/10.3171/2015.4.JNS141945.

84. Zaidi HA, Mooney MA, Levitt MR, Dru AB, Abla AA, Spetzler RF. Impact of Timing of Intervention Among 397 Consecutively Treated Brainstem Cavernous Malformations. Neurosurgery [Internet] 2017 [cited 2020 May 28];Available from: https://academic.oup.com/neurosurgery/article/298194 9/Impact

85. Garcia RM, Ivan ME, Lawton MT. Brainstem cavernous malformations. Neurosurgery. 2015;76(3):265-78. https://doi.org/10.1227/NEU. 0000000000000602

86. Chandra PS, Manjari T, Chandramouli BA, Jayakumar PN, Shankar SK. Cavernous-venous malformation of brain stem--report of a case and review of literature. Surg Neurol. 1999;52(3):280-5. https://doi.org/10.1016/S0090-3 019(99)00079-8.

87. Yamada S, Liwnicz BH, Thompson JR, Colohan AR, lacono RP, Tran JT. Pericapillary arteriovenous malformations angiographically manifested as cerebral venous malformations. Neurol Res. 2001;23(5):513-21. https://doi. org/10.1179/016164101101198767.

88. Rigamonti D, Spetzler RF. The association of venous and cavernous malformations. Report of four cases and discussion of the pathophysiological, diagnostic, and therapeutic implications. Acta Neurochir 1988;92(1-4):100-105, DOl: https://doi.org/10.1007/BF01401979.

89. Campeau NG, Lane Jl. De novo development of a lesion with the appearance of a cavernous malformation adjacent to an existing developmental venous anomaly. AJNR Am J Neuroradiol. 2005;26(1):156-9.

90. Wurm G, Schnizer M, Fellner FA. Cerebral Cavernous Malformations Associated with Venous Anomalies: Surgical Considerations. Oper Neurosurg. 2005;57(suppl_1):42-58. 
91. Georgieva VB, Krastev ED. Surgical treatment of brainstem cavernous malformation with concomitant developmental venous anomaly. Asian J. Neurosurg. 2019;14(2):557-60. https://doi.org/10.4103/ajns.AJNS_246_18.

92. Masuoka J, Matsushima T, Hikita T, Inoue E. Cerebellar swelling after sacrifice of the superior petrosal vein during microvascular decompression for trigeminal neuralgia. J Clin Neurosci Off J Neurosurg Soc Australas. 2009; 16(10):1342-4.

93. Piatt JH, Kellogg JX. A hazard of combining the infratentorial supracerebellar and the cerebellomedullary fissure approaches: cerebellar venous insufficiency. Pediatr Neurosurg. 2000;33(5):243-8. https://doi.org/10.1159/ 000055962.

94. Ferroli P, Acerbi F, Tringali G, Albanese E, Broggi M, Franzini A, et al. Venous sacrifice in neurosurgery: new insights from venous indocyanine green videoangiography: clinical article. J Neurosurg. 2011;115(1):18-23. https:// doi.org/10.3171/2011.3.JNS10620.

95. Kumral E, Bayülkem G, Evyapan D. Clinical spectrum of pontine infarction. J Neurol. 2002;249(12):1659-70. https://doi.org/10.1007/s00415-002-0879-x.

\section{Publisher's Note}

Springer Nature remains neutral with regard to jurisdictional claims in published maps and institutional affiliations.

Ready to submit your research? Choose BMC and benefit from:

- fast, convenient online submission

- thorough peer review by experienced researchers in your field

- rapid publication on acceptance

- support for research data, including large and complex data types

- gold Open Access which fosters wider collaboration and increased citations

- maximum visibility for your research: over $100 \mathrm{M}$ website views per year

At $\mathrm{BMC}$, research is always in progress.

Learn more biomedcentral.com/submissions 